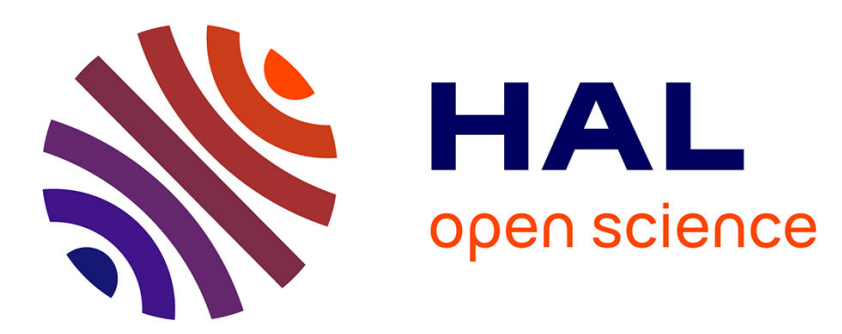

\title{
Technological innovation persistence: Literature survey and exploration of the role of organizational innovation
}

Christian Le Bas, Caroline Mothe, Thuc Uyen Nguyen-Thi

\section{To cite this version:}

Christian Le Bas, Caroline Mothe, Thuc Uyen Nguyen-Thi. Technological innovation persistence: Literature survey and exploration of the role of organizational innovation. 2011. halshs-00649095

\section{HAL Id: halshs-00649095 \\ https://shs.hal.science/halshs-00649095}

Preprint submitted on 7 Dec 2011

HAL is a multi-disciplinary open access archive for the deposit and dissemination of scientific research documents, whether they are published or not. The documents may come from teaching and research institutions in France or abroad, or from public or private research centers.
L'archive ouverte pluridisciplinaire HAL, est destinée au dépôt et à la diffusion de documents scientifiques de niveau recherche, publiés ou non, émanant des établissements d'enseignement et de recherche français ou étrangers, des laboratoires publics ou privés. 
Technological innovation persistence: Literature survey and exploration of the role of organizational innovation

Christian Le Bas, Caroline Mothe, Thuc Uyen Nguyen-Thi

Novembre 2011 


\section{GATE Groupe d'Analyse et de Théorie Économique Lyon-St Étienne}

93, chemin des Mouilles 69130 Ecully - France

Tel. +33 (0)4 72866060

Fax $+33(0) 472866090$

6, rue Basse des Rives 42023 Saint-Etienne cedex 02 - France

Tel. +33 (0)4 77421960

Fax. $+33(0) 477421950$

Messagerie électronique / Email : gate@gate.cnrs.fr

Téléchargement / Download : http://www.gate.cnrs.fr - Publications / Working Papers 


\title{
Technological innovation persistence: Literature survey and exploration of the role of organizational innovation
}

\author{
Christian Le Bas, GATE, University of Lyon, France \\ Caroline Mothe, IREGE, University of Savoie, France \\ Thuc Uyen Nguyen-Thi ${ }^{1}$, CEPS/INSTEAD, Luxembourg
}

\begin{abstract}
In this paper, we will review the literature on technological innovation persistence and provide a general theoretical framework to analyze the main determinants of this innovative behavior. Moreover, no previous empirical study has taken into account organizational innovation practices as possible determinants of innovation persistence. We will therefore include them, as previous studies have shown the interaction effects between the two types of innovation, and produce empirical results on technical innovation persistence. A multinomial probit model was used to estimate the likelihood of belonging to each of the three longitudinal innovation profiles. Results confirm the differentiated impact of determinants on process and technological innovation persistence, and the effect of R\&D intensity, R\&D cooperation and competition intensity. As hypothesized, we also found that organizational innovation is a determinant factor for innovation persistence and, more generally speaking, for technological innovation, in particular organizational practices such as knowledge management and external partnerships.
\end{abstract}

KEYWORDS: Persistence; Innovation; Technological innovation; Organizational innovation; R\&D.

\section{RESUME}

Nous faisons un survey de la littérature sur la persistance du comportement d'innovation et les différents cadres d'analyse des déterminants de ce type de comportement. On constate qu'aucune étude n'a jusqu'ici pris en compte les pratiques d'innovation organisationnelle comme possible déterminant de la persistance. Un modèle probit multinomial est estimé sur des données du Luxembourg. Les résultats confirment que l'innovation organisationnelle est un déterminant de la persistance à l'innovation.

MOTS CLEFS: Persistance; Innovation; Technologie; Organisationnelle innovation; R\&D.

\footnotetext{
${ }^{1}$ Corresponding author: CEPS/INSTEAD, 3 av de la Fonte, 4364 Esch-sur-l'Alzette, Luxembourg. Tel. : +352 585855632 ; Fax : +352 585855700. E-mail address : thithucuyen.nguyen@ceps.lu
} 


\section{Introduction}

Innovation persistence has become an important topic in applied industrial organization since the publication of the seminal paper by Geroski et al. (1997). The empirical studies that followed (Antonelli, 2011; Colombelli and von Tunzelmann, 2011; Dosi, 1997; Latham and Le Bas, 2006) have led to increased recognition that firms' competitive advantage largely depends on their ability to innovate over a long period of time. In the evolutionary tradition, sustainable growth is linked to firms' capacity to accumulate economically useful technological knowledge (Nelson and Winter, 1977; Pavitt, 2003). For the economy as a whole, the objectives are slightly different since part of the productivity growth can stem from the creation of new firms implanting new products or process technologies.

In order to assess innovation persistence empirically, we need different time periods in which to observe the innovation phenomenon. Consistent with Geroski et al. (1997), we define a firm's degree of innovation persistence as the number of consecutive years during which it has a recorded innovative output. The firm can innovate sporadically if it does so in some periods of time and not in others. When it does not innovate during two time periods, it is considered to be non-innovative.

While the various studies on persistence have shown somewhat contradictory results, no general survey has been undertaken to synthesize our knowledge on this phenomenon. The first aim of the chapter is to fill this gap. While considerable empirical evidence on the phenomenon has been gathered, the understanding of innovation persistence lacks a global theoretical framework. We here intend to delineate some of the more fruitful bodies of explanation. The second objective is to highlight the role of organizational innovation in technological innovation persistence, as this impact has often been neglected in past empirical surveys. Finally, some empirical evidence from the Luxembourg CIS will be provided in order to add to our knowledge on the main determinants of innovation persistence.

\section{2. "Scale and scope" of innovation persistence: main empirical evidence}

We here survey some of the main empirical works addressing the "scale and scope" of innovation persistence. Innovation persistence has been dealt with, measured and accounted for through different types of indicators (such as patents, major innovations, R\&D outputs) and with various databases (such as the CIS, Community Innovation Surveys).

Patent data. The very first studies to deal with innovation persistence use patenting as a reliable indicator of innovation. Geroski et al. (1997) examine the innovative history of UK firms using a patent database. Their sample contains 3304 firms that registered at least 1 patent in the period 1969-1988. It yields an important conclusion: very few innovative firms are found to be persistently innovative. They find that the number of patents granted at the beginning of an innovative period (a "spell") is a good and strong predictor of the length of such spells. However, they are not able to test the effects of firm size on the length of innovation spells. It appears that the volume of patenting or innovation activity prior to the spell under consideration explains the 
spell's length better than firm size. These results tend to emphasize that the main factor behind the persistence of innovation is the size of "innovation activity" (measured, for instance, by the volume of R\&D expenditure) more than the size of "economic activity". Because of the feasible quantitative methodology for estimating econometric relationships in this area, Geroski et al.'s (1997) study has been considered as a benchmark.

Le Bas et al. (2003) conduct an empirical analysis of French firms that made patent applications to the US Patent Office from 1969 to 1985. A total of 22000 patents were granted to 3347 firms. They confirm Geroski et al.'s (1997) main result: only 42 firms of the sample innovated continuously over the 16-year period of time studied. The paper identifies 4 types of behavior: 1 . single patentors patent over short spells (a maximum of 3 years), producing few patents (71\% of the sample); 2. heavy patentors patent over long spells (a maximum of 13 years) (2.2\%); 3 . medium patentors take out between 2 and 10 patents over a single spell only (13\%); 4. sporadic patentors patent over several spells (13.9\%). Among the most important findings is that a minimum threshold of innovation activity (here, a minimum of patenting) appears to be necessary to become a "persistent innovator". In other words, only consistent innovators could become persistent innovators. Apart from these analyses, only a very few papers (Duflos, 2006) address the issue of innovation persistence with patent data.

Major innovations and $\boldsymbol{R} \& \boldsymbol{D}$ data. Data on major innovations appear to be better for assessing innovation persistence than the patent count in that the work focuses on firms that are technically innovative and commercially successful. In the case of patents, we are not sure that the firm really innovates on the market. The use of this sort of data has been very sparse (only Geroski et al.'s (1997) study has been found), largely because of the very high costs involved in gathering relevant data for a large time period and for many technological fields. Geroski et al. (1997), besides patent data, use the SPRU data set on major innovations (a list of innovations provided by experts) as a means for approaching innovation persistence in order to carry out a complementary study looking for evidence consistent with the view that not many firms innovate persistently. Their sample consists of 1624 firms that produced at least 1 "major innovation" (in the sense of the SPRU data set) in the UK between 1945 and 1982. Their findings confirm that very few innovative firms are persistently innovative. Larger firms (measured by employment figures) are found to have longer innovation spells. However, the relationship between firm size and length of spells seems to be "highly non-linear" (Geroski et al., 1997).

Only a few studies use R\&D indicators as a relevant variable for tracking innovation persistence, such as that of Máñez Castillejo et al. (2004) on Spanish firms. It remains true that numerous studies use R\&D expenditure as an independent variable for controlling the possible effect of formal industrial research on the origin of innovation persistence (see Duguet and Monjon, 2004). By contrast, the use of homogeneous CIS data is becoming more widespread, making, amongst others things, international comparisons easier. 
CIS data. Numerous studies examine whether innovation is persistent at the firm level by using innovation surveys. ${ }^{2}$ The main studies are summarized here, while section 3 addresses some other findings. These data sets provide information on the implementation of innovation at the firm level, without any reference to their commercial success or their likely patenting status. The statistical category related to innovation is mostly based on the frame of the so-called Oslo Manual. $^{3}$

Duguet and Monjon (2004), in a study on 808 French industrial firms' innovative activity for the period 1986-1996, find that innovation persistence is strong. Around 50\% of the innovating firms in one period remain innovating one or two periods later. Moreover, a firm that has already innovated in the past is found to have a stronger probability of innovating in the future. This result witnesses a difference between the results that emerge from patent data and those built on CIS data. This could be due to the fact that the definition of innovation provided by the CIS is different from that provided by patent data. Indeed, a patent application acknowledges an invention and therefore provides a somewhat restricted image of innovation propensity as a firm may well innovate and not patent its invention. The contrary is true too: a firm might be very inventive with lots of patents but not succeed in innovating. Another explanation lies in the fact that the observation time period is shorter.

Raymond et al. (2010) measure innovation intensity with the ratio innovative sales/total sales. Exploiting a data set on three waves of CIS related to Dutch manufacturing firms, they conclude that the past shares of innovative sales condition (although to a weak extent) the current share of innovative sales. Nevertheless, they argue for a lack of persistence due to the properties of the estimations. Indeed, their study draws our attention to the crucial point that in the papers using CIS data sets, persistence is analyzed as follows: a probit model explains whether the firm innovates (or not) at time $\mathrm{t}$ by a set of independent variables including the lagged $(\mathrm{t}-1)$ dependent binary variable (if the firm innovated or not). The coefficient (if significant) related to this last variable is considered as a measure of innovation persistence (since it measures the effect of a firm's past innovation on its current decision to innovate or not). Raymond et al. (2010) show that this approach must be interpreted with caution. Two types of state dependence are in fact implicated here. The true one (recording that past innovation positively impacts the probability of innovating in the current period) and a "spurious state dependence" (some unobserved effects are correlated over time). As a consequence, when unobserved effects are correlated over time, the initial conditions have to be estimated rigorously. This entails the use of new relevant estimation procedures.

Haned (2011) illustrates the different innovation behaviors (see above) in 4 waves of the French CIS (1994 to $2006^{4}$ ). In a sample of 431 manufacturing firms, 256 firms (out of 431, thus 59\%)

\footnotetext{
${ }^{2}$ One exception is that by Antonelli et al. (2010), which is based on data from the Mediocredito Centrale (Italian bank).

${ }^{3}$ In the frame of this paper we could not give details on the measurement of innovation set out by the Oslo Manual. The reader will able to look at (among other reports) the OECD Guidelines for Collecting and Interpreting Innovation Data, 3rd Edition (Oct. 2005). Smith (2005) provides a coherent study on measuring innovation activities.
}

${ }^{4}$ The four waves are: CIS2 for 1994-1996, CIS3 for 1998-2000, CIS4 for 2002-2004 and CIS2006 for 2004-2006. 
have innovated in the 4 time periods, 129 (29\%) in 2 or 3 periods (sporadic innovators) and 33 firms are weak innovators (those that have innovated only once in the period under scrutiny). Finally, 13 non-innovators are also included in the sample. Recall that the overall number of French industrial firms in 2008 was 227900 (source: INSEE). Of course, not all of these have been surveyed (partly because of their very small size). However, there is still a huge gap between the number of firms that innovate persistently (256) and this number. Besides, Haned (2011) shows that the frequency of innovation activity in the past has a strong and significant influence on the current innovation activity. Most importantly, in all the estimations carried out, a higher coefficient is observed for firms that have innovated in each of the 3 last periods. The coefficient related to the regressor "past innovation intensity" decreases with the frequency of innovation in the past. These results suggest that firms that are "systematic" innovators are more likely to display persistent innovation behavior than sporadic or weak innovators. Supplementary estimations tend to analyze the impact of past innovation performance on innovation persistence compared with the effect of past R\&D investments. They evidence that the probability of a firm being persistent increases more when the commercial success of innovation is high in the last periods than with positive $R \& D$ investments. For this sample of French firms positive R\&D investments in each of the 3 previous periods have a positive effect on the probability of being a persistent innovator, but this effect represents half of the impact of the commercial success of innovations on innovation persistence.

Towards a greater understanding of the scope of innovation behaviors. The rich frame of CIS enables us to study not only whether the firm innovates over time but also the type of innovation implemented, making it possible to analyze the trends of innovation persistence for a particular type of innovation. Indeed, while numerous papers retain only the variable "process and/or product innovator", others distinguish whether the firm is a single persistent innovator in products or in processes. For instance, Haned (2011) finds that the coefficients of the lagged explanatory variables accounting for the frequency of past innovations are stronger and more significant for product innovators than for process innovators, and thus that the trend for persistence is larger for product innovators than for process innovators. These results are in line with those of Antonelli et al. (2010), for whom the level of persistence is higher for product innovators, Clausen et al. (2010) and Roper and Hewitt-Dundas (2008). Another type of investigation concerns the complex innovators who innovate in products and processes. Le Bas and Poussing (2011), using data from the CIS in Luxembourg, show that complex innovators are more persistent (as innovators) than single innovators (product or process).

Summarizing the main findings allows us to retain the following: 1 . if we look at the manufacturing firms (whatever their size), the population of firms that innovate persistently is very narrow; 2. if we select the large innovating firms, they tend to persist in their innovation behavior more than smaller firms; 3 . the longer the time scale related to the observation, the smaller the population of persistent innovators. 


\section{Firm innovation persistence: three complementary bodies of explanations}

\section{Type of dynamic learning or the "dynamic scale economies" hypothesis}

To explain innovation persistence, Geroski et al. (1997) propose a combination of "learning effects" in the production of innovation and positive feedback between the accumulation of knowledge and the production of innovation. In other words, the production of innovation would be strongly subject to dynamic economies of scale.

The hypothesis of knowledge accumulation stipulates that experience in innovation is associated with dynamic increasing returns in the form of learning-by-doing and learning-to-learn effects, which enhance knowledge stocks and the probability of future innovations. For example, Geroski et al. (1997) comprehend a sequence of innovations that persists over time as follows: a major innovation always opens up a series of improvements and thus minor innovations and "dynamic economies of scale" in the production of innovation. By innovating, the firm explores a process of learning and discovers new ideas by recombining (re-arranging) old ones. The more it has produced pieces of knowledge in the past, the more it is able to recombine them in order to produce new pieces of knowledge (such a process is considered and analyzed by Weitzman, 1996). This hypothesis is also acknowledged as "past innovation affects current innovation" (Duguet and Monjon, 2002). Duguet and Monjon (2002) show that this approach to innovation persistence depends on firm size: the dynamic increasing returns hypothesis seems to play a major role only for small-sized firms, whereas its strength decreases with firm size. They show the importance of formal research development activity, although they acknowledge the specific effect of previous innovation behavior (which is different from the effect of R\&D) on current innovation.

Colombelli and von Tunzelmann (2011) draw the main consequences of this approach by noting that innovation is the result of cumulative patterns and learning dynamics. This pattern of technological accumulation is at the base of the persistence of innovation. This means that current innovation is explained by past innovation, which has enduring effects as a result of cumulative knowledge and learning processes. It gives great relevance to the idea that innovation persistence is "path-dependent" - as opposed to "past-dependent". In the case of pure pastdependent effects, the processes are fully determined by the initial conditions. By contrast, pathdependent processes are affected by factors that modify the rate and direction of technological change in different time periods. As such, path-dependent processes are shaped by the localized context in which the new knowledge is implemented (Antonelli, 2008: chapter 18). The interactions between agents and networks of local actors "that allow for the exploitation of complementarities and interdependences, reinforced by the technological and industrial specialization of the area, the institutional endowment and by a common local culture of trust, based on shared practices and rules, are centripetal forces that make a base of attraction of the local system" (Colombelli and von Tunzelmann, 2011: 10).

The complex relationship between innovation persistence and profitability: the "success breeds success" hypothesis 
"Success breeds success" sometimes refers to the hypothesis that a firm can gain locked-in advantages over other firms due to successful innovations. This hypothesis holds in a few words: innovation feeds profitability, which funds innovation activities a time period later. The main difference between the two explanatory frames is that, here, the economic and commercial successes play a role.

The links between innovative persistence and economic performance are studied by Le Bas and Négassi (2002), who show that persistence has a positive impact on sectoral performance. At the firm level, there is a strong relationship between persistence in innovative behavior and persistence of above-average profits. Cefis (1999) also suggests that firms that are systematic innovators earn profits above the average and have a strong incentive to keep innovating and earning profits above the average. Among these systematic innovators, there are probably many "first movers" that achieve dynamic learning and produce persistent high levels of profit (see Mueller, 1997). Cefis and Ciccarelli (2005), on a panel of 267 UK manufacturing firms over the period 1988-1992, find a greater difference in profitability between innovators and noninnovators than between persistent innovators and non-innovators. Antonelli et al. (2010) attribute this result to the fact that past innovations have a long-lasting effect on profitability, innovation at time $t$ being positively influenced by past innovation via the greater availability of financial resources. The point of view supported by Raymond et al. (2010) deserves attention: the authors underline that many studies on the relationship between innovation and firm performance are cross-sectional. As a consequence, these studies cannot analyze the dynamics of innovation and of firm profitability, making the dynamic panel more relevant.

\section{Sunk costs in $R \& D$ activities}

Antonelli et al. (2010) interpret the evidence of persistence in innovation efforts as intertemporal stability in the undertaking of $R \& D$ efforts. Indeed, the firm always faces the choice between investing or not investing in $R \& D$ activities, a form of investment that has specific characteristics: "The creation of a R\&D laboratory is characterized by major sunk costs that imply a long term commitment. The activity of a R\&D laboratory requires that the generation of technological knowledge and the introduction of technological innovations become a systematic component of the firm strategy and innovation is a stable element of the routines of the firms" (Antonelli et al., 2010: 10). The notion of "sunk costs" effects refers to the continuity of the R\&D expenditure. As R\&D expenditure is a driver of innovation, the persistence of the former could lead to the persistence of innovation (Cohen and Klepper, 1996; Sutton, 1991). The hypothesis of sunk costs in $R \& D$ investments means that a firm deciding to engage in $R \& D$ activities has to incur start-up costs that are usually not recoverable. These sunk costs represent a barrier to both entry to and exit from R\&D activity. The presence of important sunk costs represents an essential motive for entering and staying in a specific regime of R\&D activity.

Such an analysis enables us to predict differences in terms of long-term stability between process and product innovations due to the fact that the two are not similar as far as the key core 
competences are concerned. The empirical evidence tends to show that firms implementing process innovations appear to be characterized by lower levels of persistence. This could be explained by the fact that, in the case of process innovation and during each time period, the firm has the choice between the introduction of process innovations through internal R\&D activity and the purchase of capital goods from upstream manufacturers. By contrast, product innovations "become a stable component of the strategy of firms that rely on the flows of new products as a long term component of their marketing strategies. Product innovations feed the oligopolistic rivalry in product markets" (Antonelli et al., 2010: 10). This suggests that when firms undertake different types of innovation jointly (i.e. product, process and organizational innovation), a lower degree of state dependence is expected, making such firms less persistent in innovation. The importance of R\&D as a factor "pushing" innovation persistence is verified for two countries (France and Spain) by Lhuillery (1994) and Máñez Castillejo et al. (2004).

\section{Determinants of innovation persistence}

We have studied the major papers in the recent literature addressing the topic of innovation persistence. This survey leads us to identify the main determinants of persistent innovation behaviors.

\section{Classical determinants}

Firm size. Firm size is the determinant of innovation persistence that appears the most frequently (70\%). The larger the firm is, the more important the persistence is because large firms are supposed to have more market power (Huang and Yang, 2010) and more capacity to exploit innovations. Antonelli et al. (2010) explain that smaller firms face stronger entry barriers than exit barriers. However, Napoli (2008) adds that while the linear relationship shows that firm size is important in determining innovation, the negative quadratic relationship suggests that this is only true up to a certain level: a large firm size can be detrimental to innovation. Moreover, Peters (2009) finds that firm size is only important in the manufacturing sector and Clausen et al. (2010) conclude that the effect of this variable is higher for product innovations.

Past R\&D activity. Past R\&D activity is considered as a main determinant of persistence by $60 \%$ of the authors. That fits well with the third explanation we have put forth. The more important the past activity of R\&D, the more important the probability of innovating persistently. Lelarge (2006) finds a strong correlation between the persistence of innovation and past R\&D activity. According to Antonelli et al. (2010), Huang (2008), Musolesi (2006) and Peters (2009), the probability of further innovations is affected by the sequence of innovations introduced in the past. Máñez Castillejo et al. (2004) use a panel of 383 manufacturing firms in Spain and conclude that R\&D activities are subject to dynamic economies of scale and confirm the successbreeds-success hypothesis. Moreover, according to Napoli (2008), the commitment to innovation can be further reinforced by past R\&D expenditure. As for Duflos (2006), he finds that present success depends on the technological importance of past innovation. Finally, Raymond et al. (2010) find that past non-R\&D performers are less successful than past R\&D performers. 
Intensity of $R \& D$ and the role of sunk costs. Of the authors $50 \%$ consider the intensity of $R \& D$ to be an important factor of persistence. Firms that have strong $R \& D$ activity are more prone to innovating persistently. Several authors, such as Triguero-Cano and Corcoles-Gonzalez (2010), Johansson and Lööf (2010) and Clausen et al. (2010), consider this factor as an innovation strategy with persistent R\&D efforts. Moreover, Máñez Castillejo et al. (2004) highlight the existence of sunk costs in firms' R\&D activities and that these sunk costs explain the persistence of $R \& D$ activities (a barrier to both entry to and exit from R\&D activities). Nevertheless, there is a quick depreciation of the effects of prior $R \& D$ activities over time (there are not many differences between the re-entry costs of a firm that previously performed R\&D activities and a firm that has never conducted $R \& D$ ).

Technological opportunity. Technological opportunity is also very important as half of the authors mention it. Firms that deal with high-technology or scientific industries (Huang and Yang, 2010) have more chance of innovating persistently. Lelarge (2006) and Raymond et al. (2010) talk of a technological frontier: industries that are closer to the technological frontier are more likely to display persistence in innovation. Máñez Castillejo et al. (2004) discuss the high degree of appropriability of R\&D results. Finally, Clausen et al. (2010) add that high technology is assimilated into product innovation whereas low technology corresponds more to process innovation.

Internationalization. About $40 \%$ of the authors consider export activity to be a substantial factor of persistence. The more the firm is internationalized, the greater the probability of innovating persistently. Máñez Castillejo et al. (2004) explain that innovation is crucial to face more competitive international markets. Moreover, Peters (2009) and Rogers (2004) specify that internationalization is only important for manufacturing firms.

Accumulation of knowledge. This determinant refers to the hypothesis of the learning-by-doing effect, as explained by Huang and Yang (2010). One-third of the authors think that this factor is important. According to Antonelli and Scellatto (2009), the probability of introducing further innovations is affected by the capabilities of each firm to accumulate and exploit technological knowledge. Knowing how to accumulate and use knowledge capital (internal and external sources) is thus very important.

Skills (human capital). According to $30 \%$ of the authors, it is crucial for an innovative firm to have strong human capital. Triguero-Cano and Corcoles-Gonzalez (2010) highlight the importance of employing graduates and engineers. Rogers (2004) states that it is very important to have good management training.

Ownership. This determinant is dealt with positively by $30 \%$ of the documents. Johansson and Lööf (2010) and Raymond et al. (2010) explain that belonging to a multinational or being part of a group could be a factor of persistence. Furthermore, foreign participation seems to have a positive impact on persistence according to Máñez Castillejo et al. (2004) and Wziątek-Kubiak and Pęczkowski (2011). Finally, foreign ownership is seen as a threat to innovation by $10 \%$ of the authors. According to Rogers (2004), foreign firms report less innovation.

Competition. The degree of competition is considered as a factor of persistence by $25 \%$ of the authors. The fiercer the competition is, the more firms are prone to innovating persistently. Indeed, market pressure is a good incentive to innovate, especially when the competitive pressure comes from industrials of the same market (Antonelli et al., 2010). Máñez Castillejo et al. (2004) link this factor with internationalization: firms in more competitive markets have 
greater incentives to undertake R\&D activities. Finally, Triguero-Cano and Corcoles-Gonzalez (2010) consider the presence of other industrial innovators in the same industry in other regions as a threat to innovating persistently.

Industrial sector and market specificity. Of the authors $20 \%$ deal positively with this determinant. Persistence could be influenced by the sectoral affiliation of the firm (Antonelli $e t$ al., 2010) or the market structure: a highly concentrated industry (Cefis and Ciccarelli, 2004) or a market with more demand pull (Raymond et al., 2010). The sector effect is without doubt the most controversial. Some studies do not support the existence of industrial sector effects. Finally, Triguero-Cano and Corcoles-Gonzalez (2010) highlight the importance of market dynamics.

Capital intensity. The issue of capital intensity is considered by $20 \%$ of the authors. Antonelli et al. (2010) reveal the importance of the level of fixed capital investments, as well as Huang and Yang (2010). Peters (2009) explain that firms that are not financially constrained (good financial liquidity and support of public funding) have more chance of innovating persistently.

Other determinants. About $10 \%$ of the documents deal with such other likely determinants as market share, firm localization, networks effects and firm age. Concerning the market share of a firm, the higher it is, the more the probability of innovating persistently increases (Cefis and Ciccarelli, 2004; Máñez Castillejo et al. 2010). Moreover, the market concentration seems to have no impact on innovation (Peters, 2009) or a negative impact (Rogers, 2004; Triguero-Cano and Corcoles-Gonzalez, 2010).With regard to firm localization, firms that are located where knowledge externalities/levels of TFP are important have an advantage (Antonelli et al., 2010). Finally, concerning networks, the more networks a firm has, the greater its probability of innovating (Wziątek-Kubiak and Pęczkowski, 2011). Rogers (2004) adds that this association between network and innovation is only true for manufacturing firms. The age of a firm is considered to be unfavourable to innovation by $10 \%$ of the authors. Triguero-Cano and CorcolesGonzalez (2010) explain that age is favorable for R\&D activity but not for the propensity to innovate.

\section{The neglected role of organizational innovation in technological innovation}

To this list of antecedents of technological innovation persistence we will add a less studied determinant, namely organizational innovation. While numerous studies highlight the importance of technological innovation as a driver of organizational changes within the firm (Dougherty, 1992; Henderson and Clark, 1990), another research stream points out the inverse relationship by stressing the role of organizational innovation in enhancing flexibility and creativity, which in turn facilitates the development of technological innovation. Lokshin, van Gils and Bauer (2008) show empirically that firms that implement a combination of customer and organizational skills tend to introduce more technological innovation, a result that is further confirmed by Mothe and Nguyen-Thi (2010, 2011). In line with these works, we will consider organizational practices as an input to the firm's innovation process, and thus to innovation persistence. The impact of three types of organizational innovation practices will be analyzed.

The first category of organizational innovation refers to the introduction of knowledge management systems such as management skills or sharing, coding and storing knowledge, which are usually associated with a higher level of flexibility, adaptability, competitive advantage and organizational performance (Grant, 1996; Prahalad and Hamel, 1990; Spicer and 
Sadler-Smith, 2006; Alänge and Steiber, 2011). Various works recognize the positive impact of KM strategies but few provide conclusive evidence (Becerra-Fernandez and Sabherwal, 2001), some even reporting weak significance of the relationship between the two (Chen, Feng and Liou, 2004). Shin (2004) underlines that the high costs generated by the implementation of such a strategy may impede a firm's performance. Kremp and Mairesse (2004) find, however, that firms with knowledge management policies are likely to innovate more extensively and to have higher productivity. Uhlaner et al. (2007) show, for a panel of Dutch firms, that firms that implement knowledge management have higher growth than others.

The second category refers to the changes to the work organization. According to the OECD (2005), new work practices are related to lean and just-in-time production, decentralized decision-making, team work and shared rewards. Implementing new work organization could result in substantial improvements in organizational flexibility, which in turn lead to improved firm efficiency and performance. Previous empirical studies show, however, controversial results on the benefits of changes in work organization. Ichniowski et al. (1997) find, for a sample of 36 homogeneous steel production lines, that using a set of innovative work practices such as teams, flexible job assignments or training leads to higher output levels and product quality. Bresnahan, Brynjolfsson and Hitt (2002) highlight the complementary nature of product and service innovation, information technology and workplace reorganization, showing that new work practices only result in improvements in firm performance when they are combined with heavy investments in either human capital or ICT.

The third organizational innovation practice considered refers to external relations with other firms or public institutions, through alliances, partnerships, outsourcing or sub-contracting. Vertical cooperation with customers and suppliers is theoretically assumed to enhance firm efficiency by reducing the uncertainty related to the introduction of new products or services to the market, contributing vital information on technologies and changing market needs and facilitating market expansion, particularly when the innovation is new and complex (Klomp and van Leeuwen, 2001; von Hippel, 1988). Firms may also cooperate with universities and research institutes for new scientific and technological knowledge, i.e. technology evaluation, anticipation of social effects, access to equipment and techniques, new technological options, etc. External relations are thus considered to be important for enhancing firms' innovative capability.

\section{Persistence and organizational innovation: some empirical evidence}

\section{Data, variables and methodology}

Numerous studies investigate the persistence of technological innovation. However, the link with organization innovation remains a black box even though this type of innovation has received increased interest in recent years (for a review, see Mothe and Nguyen-Thi, 2011). We therefore aim to fill this gap with data stemming from two waves of the Luxembourgish Community Innovation Survey (CIS), CIS2006 for the period from 2004 to 2006 and CIS2008 for 2006 to 
2008. The surveys were coordinated by EUROSTAT and carried out by CEPS/INSTEAD ${ }^{5}$ in collaboration with STATEC ${ }^{6}$. The CIS2006 encompassed 1491 enterprises: 320 from the manufacturing sector and 1158 from the service sector. The target population covered $99.5 \%$ of Luxembourg firms. A sample of 644 firms received the questionnaire (220 manufacturing and 411 service firms). Due to the very high response rate (88\%), a no-response survey was not deemed necessary. After correcting for unusable responses, we were able to use a final sample of 568 firms with more than 10 employees (the target population of Community Innovation Surveys) in the manufacturing (212 firms, 37\% of the total) and service sectors (356 firms, $63 \%$ of the total). The CIS2008 was carried out in 2010. The sample contains 615 firms with more than 10 employees, 405 in services $(65.9 \%)$ and 210 in the manufacturing sector $(34.1 \%)$. Of these firms, $52 \%$ have between 10 and 49 employees, $35 \%$ between 50 and 249 and $13 \%$ more than 249 employees.

Using these data, we constructed a longitudinal data set of firms that were interviewed in both surveys, resulting in a final sample of 287 representative firms over the period from 2004 to 2008 (53\% in services and $47 \%$ in manufacturing). An important advantage of the data set is the large set of organizational practices implemented in the past, allowing us to control for the role of non-technological factors in determining innovation persistence by taking into account the substantial time lag usually associated with the return on investment of such medium- to longterm innovation strategies.

In order to study the effect of non-technological innovation strategies - defined here as organizational - on technological innovation through product and process innovations, we defined two dependent variables on the basis of the "yes-no" question on the introduction by firms of new or significantly improved products during the three years from 2004 to 2006 (CIS2006) and from 2006 to 2008 (CIS2008). We distinguished among three types of innovation profiles: (1) the persistent innovator introduced technological innovations in both reference periods; (2) the sporadic innovator introduced innovations in only one of the two reference periods; and (3) the recurrent non-innovator never innovated during the whole four-year period.

A multinomial probit model was used to estimate the likelihood of belonging to each of the three longitudinal innovation profiles (with recurrent non-innovation as the reference). This allowed us to investigate the correlations between different innovation profiles that are conditional on organizational innovation and a set of explanatory variables. All these variables are lagged, steeming from the CIS2006. Our underlying hypothesis is that there is a close relationship between innovation activities implemented in the past and technological innovation and that organizational innovation may play a crucial role in explaining the persistence of technological innovation.

We measured organizational innovation through 3 variables: (1) new business practices and knowledge management; (2) new methods of workplace organization; and (3) new methods of organizing external relations. These are equal to 1 if the firm has introduced such practices and

\footnotetext{
${ }^{5}$ International Network for Studies in Technology, Environment, Alternatives, Development

${ }^{6}$ Central Service of Statistics and Economic Studies
} 
to 0 otherwise. A total of $43 \%, 38 \%$ and $27 \%$ of innovative firms implemented, respectively, new knowledge management systems, methods of workplace organization and methods of organizing external relations. For the purpose of our study, a composite measure of organizational innovation was also introduced, taking the value 1 if firms adopted at least 1 of the above practices and the value 0 otherwise.

The R\&D efforts are represented through two innovation activities performed by firms: (1) inhouse $R \& D$ and (2) external $R \& D$ and the acquisition of technologies and knowledge (henceforth called "external R\&D"). Firms that have introduced product or process innovations were asked whether they had engaged in internal and external $R \& D$ activities. We thus determined two binary variables: a firm's probability of investing in internal R\&D (internal $R \& D$ ) and in external $\mathrm{R} \& \mathrm{D}$ (external $R \& D$ ). The $R \& D$ intensity variable is defined as the ratio of $R \& D$ expenditure per employee for firms that reported engagement in $R \& D$ activities at the time of the survey.

We also controlled for the proximity to science. In both CIS surveys, firms were asked to rate the importance of different external sources of information for their innovation activities. The dummy variable science sources is coded 1 if the sources of information stemming from institutional research (universities, other higher education institutions, government, public research institutes) are crucial for firm innovation activities and 0 otherwise. In the sample $29 \%$ of the observations state the crucial importance of science sources.

Two binary variables on appropriability conditions were included. Strategic protection is equal to 1 if the score of the importance of the strategic protection methods "secrecy", "complexity of design" or "lead-time advantage over competitors" is "crucial" and 0 otherwise. Formal protection is equal to 1 if the score of the importance of the formal protection methods "patents", "trademarks", "registration of design patterns" or "copyrights" is "crucial" and 0 otherwise. Firms were also asked to rate the degree of competition of the market on a Likert scale from 0 (no effective competition) to 3 (very intensive). On the basis of this information, we constructed the variable competition intensity. Firm size was measured by the natural logarithm of the number of employees. We also introduced a dummy variable of group belonging, taking the value 1 if the firm belongs to a group and 0 otherwise. The sector of activity (services/manufacturing) was further refined with a group of sub-sector dummies according to the two-digit NACE classification. For manufacturing, two sub-sectors were divided according to the OECD (2001) definition: (1) high-technology industries and (2) medium- and lowtechnology industries (reference). For services, four sub-sector dummies were included: (1) R\&D engineering activities and consultancy, technical testing and analysis; (2) computer activities; (3) financial activities; and (4) wholesale trade, transport and communication (reference).

\section{Estimation results}

Table 1 provides the results of the multinomial probit estimation for all the dependent variables. Based on the corresponding likelihood ratio test, we confirmed the appropriateness of using a multinomial probit model rather than individual probit estimations when rejecting the hypothesis that the error terms are uncorrelated. The results show that the aggregated measure of organizational innovation has a strong positive impact on firms' likelihood of being persistent compared with the profile of non-innovation recurrence. At the same time, we also observed that 
sporadic innovation and organizational innovation are closely associated with regard to the noninnovation profile. As a consequence, these results provide support for the idea that nontechnological innovation is specifically a determinant of product innovation as a whole, not only of its persistence. On the contrary, organizational innovation matters strongly for process innovation persistence, thus confirming our research hypothesis of the positive role of nontechnological innovation on technological innovation persistence while no evidence was found for the sporadic alternative.

\section{- TABLE 1 HERE -}

As far as individual practices are concerned, knowledge management practices that help to use external information and internal skills better increased the likelihood of being persistent in product innovation, corroborating the idea that knowledge management strategies are associated with more flexibility, adaptability and competitive advantage. Firms have opportunities to increase their innovation capacity when they expand, disseminate and exploit organizational knowledge internally, as well as share, transfer and receive knowledge from external partners (Spicer and Sadler-Smith, 2006). No evidence was found for process innovation. Rather surprisingly, the introduction of new or improved methods of workplace organization such as lean and just-in-time production, decentralized decision-making, team work and shared rewards contributed negatively to product innovation persistence. On the contrary, workplace organization is significant and positive for both persistence and sporadic alternatives in process innovation. External relations through alliances, partnerships, outsourcing or sub-contracting are significant for both product and process innovation persistence, confirming the previous results highlighting the importance of external relationships for innovation (Evangelista, 2000; Love and Mansury, 2007).

Among other explanatory variables, as expected, firms investing in external R\&D and the acquisition of external knowledge were more likely to innovate continuously in products and processes during the period 2004-2008. In-house R\&D undertaken within the firm during the past is strongly and positively associated with persistence and sporadic alternatives in product innovation while no evidence was found for process innovation. Surprisingly, however, past R\&D intensity has a positive effect only on sporadic alternatives, thus reflecting the acknowledged role of R\&D expenditure in both product and process innovations but no evidence of such an impact of R\&D intensity for innovation persistence.

Strategic protection methods are strongly and positively associated with the persistence of product innovation while being negatively associated with sporadic product innovation during 2004-2008. On the contrary, firms using strategic protection are more likely to introduce process innovation in a sporadic way. The formal protection had strong and significant effects on product and process innovations as well as on process innovation persistence. In line with other empirical works (e.g. Raymond et al., 2010), we used information sources from public and private research institutions to control for proximity to sciences. The results are somewhat counter-intuitive: science sources have a strong and negative effect on product and process innovation persistence. On the contrary, firms perceiving crucial information sources for their innovation are more likely to introduce product and process innovation sporadically. 
The estimation results also show a significant and positive effect of competition intensity on innovation persistence, supporting our expectations and previous empirical research (Antonelli et al., 2010). Belonging to a group does not have any impact on innovation persistence. In order to control for differences in the innovation profiles of different sub-sectors of activities, we introduced sub-sector dummies to the model. The model shows the importance of firm size in explaining the persistence of innovation, in particular regarding product innovation, in line with our hypothesis. Rather surprisingly, we found that more technologically advanced manufacturing industries (e.g. high-tech) were more likely to introduce product innovation in a sporadic manner during the period 2004-2008 while they were not likely to display product innovation persistence. As expected, knowledge-intensive business services (KIBS) such as R\&D, engineering and consultancy, and computer activities are more likely to innovate continuously in time than less knowledge-intensive sectors (wholesale trade was taken as the reference). For our sample, this result allows us to confirm previous research highlighting the significant differences between sub-sectors of service activities.

\section{Discussion and conclusion}

Innovation persistence is an essential topic if one is to have a relevant understanding of the dynamic of technological change and to account for firms' economic growth determinants. In this paper we reviewed many researches and point out some of the most important factors underpinning firm innovation persistence. Some of the basic mechanisms that enable firms to sustain innovation over time have been outlined. We also explored a new promising avenue for research aiming to link organizational and technological innovations. We found that organizational innovation is a determinant factor for innovation persistence and, more generally speaking, for technological innovation, confirming previous works (Mothe and Nguyen-Thi, 2011).

One crucial variable at the core of innovation persistence lies in the link to R\&D activities. Our results confirm previous results which state that firms with a strong R\&D activity are more prone to persistently innovate. A more detailed analysis showed that internal R\&D explains persistent product innovation, whereas external $\mathrm{R} \& \mathrm{D}$ is a determinant for all types of persistence (product and process). This could be explained by the presence of sunk costs, which are more important for external than for internal R\&D. Moreover, our sample includes $66 \%$ of service firms (financial and computer activities), for which process activities and collaboration with clients are key.

With respect to other classical determinants of innovation persistence, our results are in line with previous findings. All the classical variables (except the "part of a group" one) have an impact on innovation persistence. As far as sectors of activity are concerned, it is to be noted that, as expected, computer activities score very high on process innovation persistence - whereas financial activities are not engaged in product innovation persistence. The specificities of these two major service sub-sectors call for more research into the differentiated characteristics and determinants of product versus process innovation persistence.

The importance of other determinants, especially organizational innovation, brings us to acknowledge that R\&D activities are becoming more and more complex. For instance, today's open innovation practices seem to move beyond the traditional links between internal R\&D investments and innovation. In the open innovation paradigm, firms increasingly find innovation 
ideas through markets and external partnership. Such a shift in the vision of innovation entails significant changes as far as the underlying learning processes are concerned. Innovation involves many factors in addition to targeted $\mathrm{R} \& \mathrm{D}$ (for instance, design is now a better known source of technological improvement). One consequence is that firms' internal R\&D activities should not be confused with the overall learning process on which innovation can be founded. In this spirit the influence of organizational change on technological innovation (and of organizational innovation, as documented in this chapter) needs further research.

Thanks to the important amount of available data stemming mainly from CIS surveys, we can expect further progress in dealing with some important issues related to innovation persistence. Some new research topics deserve further analyses. To date, the relationships between innovation persistence and firms' economic performance are still unknown. The study of different persistence patterns of complex (i.e. process and product) innovators and simple (i.e. process or product) innovators is also worth investigating further. This would make it possible to better identify the implications of innovation persistence in terms of technology and firm strategy. The development of cross-country and cross-industry comparisons addressing innovation persistence patterns also seem to be of some interest. All these improvements in research on innovation persistence have implications for the analysis of the sustainable dynamics of firms, industries and regions. ${ }^{7}$

\section{References}

Alänge, S. and A. Steiber. 2011. Diffusion of organisational innovations: an empirical test of an analytical framework. Technology Analysis \& Strategic Management 23, no. 8: 881-897.

Antonelli, C. 2008. Localized Technological Change. Towards the Economics of Complexity. Routledge, London.

Antonelli, C. 2011. Handbook on the Economic Complexity of Technological Change. Edward Elgar, Cheltenham.

Antonelli, C., Crespi, F. and G. Scellato. 2010. Inside Innovation Persistence: New Evidence from Italian Micro-data, Dipartimento di Economia "S. Cognetti de Martiis" LEI \& BRICK Laboratorio di economia dell'innovazione "Franco Momigliano", Bureau of Research in Innovation, Complexity and Knowledge, Collegio Carlo, University of Turin.

Becerra-Fernandez, I. and R. Sabherwal. 2001. Organizational knowledge management: A contingency perspective. Journal of Management Information Systems 18, no. 1: 23-55.

Bresnahan, T. F., Brynjolfsson, E. and L. M. Hitt. 2002. Information technology, workplace organization and the demand for skilled labor: Firm-level evidence. The Quarterly Journal of Economics 117, no. 1: 339-376.

\footnotetext{
${ }^{7}$ The comments of Giuseppe Scellatto (Politecnico di Torino) are acknowledged.
} 
Cefis, E. 1999. Innovation and Industrial Dynamics: The Case of High Speed Trains in Italy. Quaderni del Dipartimento di Scienze Economiche, no. 15/1999, University of Bergamo, Bergamo.

Cefis, E. and Ciccarelli, M. 2004. Profit differentials and innovation. Economics of Innovation and New Technology 14, no. 1-2: 43-61.

Cefis, E. and M. Ciccarelli. 2005. Profit differentials and innovation. Economics of Innovation and New Technology 14: 43-61.

Chen, E. T., Feng, K. and W. Liou. 2004. Knowledge management capability and firm performance: An empirical investigation. Proceedings of the Tenth Americas Conference on Information Systems, August 5-8, New York, 2255-2262.

Clausen, T. H., Pohjola, M., Sapprasert, K. and B. Verspagen. 2010. Innovation Strategies as a Source of Persistent Innovation. TIK Working Paper No. 20100617.

Cohen, W. M. and S. Klepper. 1996. A reprise of size and R\&D. Economic Journal 106, no. 437: 925-957.

Colombelli, A. and N. von Tunzelmann. 2011. Persistence of innovation and path dependence. In C. Antonelli (ed.) Handbook on the Economic Complexity of Technological Change. Edward Elgar, Cheltenham.

Dosi, G. 1997. Opportunities, incentives and the collective patterns of technological change. The Economic Journal 107, no. 444: 1530-1547.

Dougherty, D. 1992. A practice-centered model of organizational renewal through product innovation. Strategic Management Journal, Summer Special Issue 13 : 77-92.

Duflos, G. 2006. Persistence of Innovation, Technological Change and Quality-Adjusted Patents in the US Pharmaceutical Industry. Cahier de la MSE 2006.29.

Duguet, E. and S. Monjon. 2002. Creative Destruction and the Innovative Core: Is Innovation Persistent at the Firm Level? UCL Discussion Paper 02-07.

Duguet, E. and S. Monjon. 2004. Is Innovation Persistent at the Firm Level? An Econometric Examination Comparing the Propensity Score and Regression Methods. Université PanthéonSorbonne (Paris 1).

Evangelista, R. 2000. Sectoral patterns of technological change in services. Economics of Innovation and New Technology 9: 183-221.

Geroski, P., Van Reenen, J. and C.F. Walters. 1997. How persistently do firms innovate? Research Policy 26: 33-48.

Grant, R. M. 1996. Prospering in dynamically-competitive environments: Organizational capability as knowledge integration. Organization Science 4: 375-387.

Haned, N. (2011). Firm Performance, Sources and Drivers of Innovation and Sectoral Technological Trajectories. An Empirical Study on Recent French CIS. Thèse de sciences économiques, Université Lumière Lyon 2.

Henderson, R. M. and K. B. Clark. 1990. Architectural innovation: The reconfiguration of existing product technologies and the failure of established firms. Administrative Science Quarterly 35, no. 1: 9-22. 
Huang, C.-H. 2008. A note on the persistence of firms' innovation behavior: A dynamic random effect probit model approach. Economics Bulletin 15, no. 5: 1-9.

Huang, C.-H. and C.H. Yang. 2010. Persistence of innovation in Taiwan's manufacturing firms. Taiwan Economic Review 38, no. 2: 199-231.

Ichniowski, C., Shaw, K. and G. Prenushi 1997. The effects of human resource management practices on productivity: A study of steel finishing lines. American Economic Review 87: 291313.

Johansson, B. and H. Lööf. 2010. Innovation Strategy and Firm Performance. What is the LongRun Impact of Persistent $R \& D$ ? Working Paper Series in Economics and Institutions of Innovation 240, Royal Institute of Technology, CESIS - Centre of Excellence for Science and Innovation Studies.

Klomp, L. and G. van Leeuwen 2001. Linking innovation and firm performance: A new approach. International Journal of the Economics of Business 8, no. 3: 343-64.

Kremp, E. and J. Mairesse. 2004. Knowledge Management, Innovation and Productivity: A Firm Level Exploration Based on French Manufacturing CIS3 Data. NBER Working Paper 10237.

Latham, W. and C. Le Bas. (eds). 2006. The Economics of Persistent Innovation: an Evolutionary View. Springer.

Le Bas, C. and N. Poussing. 2011. Is Complex Innovation More Persistent than Single? An Empirical Analysis of Innovation Persistence Drivers. CEPS/INSTEAD Working Paper.

Le Bas, C. and S. Négassi. 2002. Les Structures des Activités d'Innovation en France et Comparaison avec Celles des Principaux Partenaires Commerciaux. Final Report, Convention d'Etude Number 19/2000. Commissariat Général Du Plan, Paris, November 2002.

Le Bas, C., Cabagnols, A. and C. Gay. 2003. An evolutionary view on persistence in innovation: An empirical application of duration models. In P. Saviotti (ed.) Applied Evolutionary Economics. Edward Elgar.

Lelarge, C. 2006. Les entreprises industrielles françaises sont-elles à la frontière technologique? Revue Economique 57, no. 3 : 473-484.

Lhuillery, S. 1994. Warum hören Unternehmen auf, innovativ zu sein? ZEW Wirtschaftsanalysen 2 , no. $4: 401-414$.

Lokshin, B., van Gils, A. and E. Bauer. 2008. Crafting Firm Competencies to Improve Innovative Performance. Working Paper, UNU-MERIT.

Love, J. H. and M. A. Mansury. 2007. External linkages, R\&D and innovation performance in US business services. Industry and Innovation 14, no. 5: 477-496.

Máñez Castillejo, J. A., Rochina Barrachina, E., Sanchis Llopis, Z. and J.A. Sanchis Llopis. 2004. A dynamic approach to the decision to invest in $R \& D$. The role of sunk costs. Mimeo.

Máñez Castillejo, J. A., Rochina-Barrachina, M.E. and J.A. Sanchis Llopis. 2010. Does firm size affect self-selection and learning-by-exporting? The World Economy, forthcoming.

Mothe, C. and T.U. Nguyen-Thi. 2010. The link between non technological innovations and technological innovation. European Journal of Innovation Management 13, no. 3: 313-332. 
Mothe, C. and T.U. Nguyen-Thi. 2011. Non-technological and technological innovations: Do services differ from manufacturing? An empirical analysis of Luxembourg firms. International Journal of Technology Management, forthcoming.

Mueller, D. 1997. The persistence of profits above the norm. Economica 44, no. 176: 369-380.

Musolesi, A. 2006. Dynamique de l'innovation dans les services français. no. 2006-06, LEG Working Paper - Economie de LEG, Laboratoire d'Economie et de Gestion, CNRS.

Napoli, R. 2008. Innovation in the financial sector: Persistence and Schumpeterian hypotheses. Journal of Service Science and Management 1: 215-226.

Nelson, R. and S. Winter. 1977. In search of useful theory of innovation. Research Policy 6: 3676.

OECD 2001. Science and Technology Industry Scoreboard 2001. Paris.

OECD 2005. The Measurement of Scientific and Technological Activities - Proposed Guidelines for Collecting and Interpreting Technological Innovation Data. Oslo Manual. Paris.

Pavitt, K. 2003. The Process of Innovation. SPRU Electronic Working Paper Series, no. 89. August.

Peters, B. 2009. Persistence of innovation: Stylised facts and panel data evidence. The Journal of Technology Transfer 34, no. 2: 226-243.

Prahalad, C. K. and G. Hamel. 1990. The core competence of the corporation. Harvard Business Review 3: 79-91.

Raymond, W., Mohnen, P., Palm, F. and S. van der Loeff. 2010. Persistence of innovation in Dutch manufacturing: Is it spurious? Review of Economics and Statistics 92: 495-504.

Rogers, M. 2004. Networks, firm size and innovation. Small Business Economics 22, no. 2 : $141-153$.

Roper, S. and N. Hewitt-Dundas. 2008. Innovation persistence: Survey and case-study evidence. Research Policy 37: 149-162.

Shin, M. 2004. A framework for evaluating economics of knowledge management systems. Information and Management 42: 179-196.

Smith K. H. 2005. Measuring innovation. In The Oxford Handbook of Innovation. Oxford University Press, New York, US, 148-177.

Spicer, D. P. and E. Sadler-Smith. 2006. Organizational learning in smaller manufacturing firms. International Small Business Journal 24, no. 2: 133-158.

Sutton, J. 1991. Sunk Costs and Market Structure. The MIT Press, Cambridge.

Triguero-Cano, A. and D. Córcoles-González. 2010. Understanding the innovation: An analysis of persistence for Spanish manufacturing firms. Paper presented at the Twelfth Annual Conference ETSG, 9-11 September 2010, Lausanne.

Uhlaner, L., Wright, M. and M. Huse. 2007. Private firms and corporate governance: An integrated economic and management perspective. Small Business Economics 29: 225-241.

Von Hippel, E. 1988. The Sources of Innovation. Oxford University Press. 
Weitzman, M. L. 1996. Hybridizing growth theory. American Economic Review 86: 207-212.

Wziątek-Kubiak, A. and M. Pęczkowski. 2011. The heterogeneity of firms' response to obstacles to innovation: Persistent versus occasional innovators. Paper presented at the DIME Final Conference, 6-8 April 2011, Maastricht. 
Table 1: Estimation results of multinomial probit

\begin{tabular}{|c|c|c|c|c|c|c|c|c|}
\hline \multirow[t]{2}{*}{ VARIABLES } & \multicolumn{4}{|c|}{ Product } & \multicolumn{4}{|c|}{ Process } \\
\hline & Persistent & Sporadic & Persistent & Sporadic & Persistent & Sporadic & Persistent & Sporadic \\
\hline & \multicolumn{2}{|c|}{ Aggregated OI } & \multicolumn{2}{|c|}{ Detailed OI } & \multicolumn{2}{|c|}{ Aggregated $\mathrm{OI}$} & \multicolumn{2}{|c|}{ Detailed $O I$} \\
\hline Organizational innovation & $\begin{array}{c}0.599 * * * \\
(0.127)\end{array}$ & $\begin{array}{c}1.428 * * * \\
(0.171)\end{array}$ & & & $\begin{array}{c}0.527 * * * \\
(0.136)\end{array}$ & $\begin{array}{l}0.0310 \\
(0.199)\end{array}$ & & \\
\hline Knowledge management & & & $\begin{array}{c}0.972 * * * \\
(0.160)\end{array}$ & $\begin{array}{c}0.665^{* * * *} \\
(0.198)\end{array}$ & & & $\begin{array}{c}0.222 \\
(0.163)\end{array}$ & $\begin{array}{c}-0.0250 \\
(0.235)\end{array}$ \\
\hline Workplace organization & & & $\begin{array}{c}-0.321 * \\
(0.183)\end{array}$ & $\begin{array}{c}0.258 \\
(0.222)\end{array}$ & & & $\begin{array}{c}0.348 * * \\
(0.173)\end{array}$ & $\begin{array}{c}0.795 * * * \\
(0.231)\end{array}$ \\
\hline External partnerships & & & $\begin{array}{c}0.410^{* *} \\
(0.182)\end{array}$ & $\begin{array}{c}1.167 * * * \\
(0.208)\end{array}$ & & & $\begin{array}{l}0.319^{*} \\
(0.173)\end{array}$ & $\begin{array}{c}-0.870 * * * \\
(0.243)\end{array}$ \\
\hline Internal R\&D & $\begin{array}{c}1.637 * * * \\
(0.307)\end{array}$ & $\begin{array}{c}1.195 * * * \\
(0.322)\end{array}$ & $\begin{array}{c}1.570 * * * \\
(0.316)\end{array}$ & $\begin{array}{c}1.343 * * * \\
(0.336)\end{array}$ & $\begin{array}{c}0.379 \\
(0.237)\end{array}$ & $\begin{array}{c}0.227 \\
(0.272)\end{array}$ & $\begin{array}{c}0.497 * * \\
(0.242)\end{array}$ & $\begin{array}{c}0.153 \\
(0.278)\end{array}$ \\
\hline External R\&D & $\begin{array}{c}1.680 * * * \\
(0.202)\end{array}$ & $\begin{array}{c}0.782 * * * \\
(0.211)\end{array}$ & $\begin{array}{c}1.801 * * * \\
(0.210)\end{array}$ & $\begin{array}{c}1.070 * * * \\
(0.221)\end{array}$ & $\begin{array}{c}2.589 * * * \\
(0.193)\end{array}$ & $\begin{array}{c}2.775 * * * \\
(0.272)\end{array}$ & $\begin{array}{c}2.639 * * * \\
(0.200)\end{array}$ & $\begin{array}{c}2.607 * * * \\
(0.286)\end{array}$ \\
\hline Intensity R\&D & $\begin{array}{l}-1.453 \\
(2.122)\end{array}$ & $\begin{array}{c}12.93 * * * \\
(2.087)\end{array}$ & $\begin{array}{l}-2.031 \\
(2.082)\end{array}$ & $\begin{array}{c}11.91 * * * \\
(2.019)\end{array}$ & $\begin{array}{c}2.204 \\
(1.927)\end{array}$ & $\begin{array}{c}5.803 * * * \\
(1.996)\end{array}$ & $\begin{array}{c}2.982 \\
(1.950)\end{array}$ & $\begin{array}{c}6.355^{* * * *} \\
(2.029)\end{array}$ \\
\hline Science sources & $\begin{array}{c}-0.850 * * * \\
(0.200)\end{array}$ & $\begin{array}{c}1.449 * * * \\
(0.202)\end{array}$ & $\begin{array}{c}-0.955^{* * *} * \\
(0.207)\end{array}$ & $\begin{array}{c}0.984 * * * \\
(0.212)\end{array}$ & $\begin{array}{c}-0.385^{* *} \\
(0.186)\end{array}$ & $\begin{array}{c}0.882 * * * \\
(0.204)\end{array}$ & $\begin{array}{c}-0.586 * * * * \\
(0.198)\end{array}$ & $\begin{array}{c}1.117 * * * \\
(0.227)\end{array}$ \\
\hline Strategic protection & $\begin{array}{c}0.408 * * * \\
(0.153)\end{array}$ & $\begin{array}{c}-0.480 * * \\
(0.201)\end{array}$ & $\begin{array}{c}0.426 * * * \\
(0.156)\end{array}$ & $\begin{array}{c}-0.366^{*} \\
(0.204)\end{array}$ & $\begin{array}{c}0.164 \\
(0.154)\end{array}$ & $\begin{array}{c}1.391 * * * \\
(0.258)\end{array}$ & $\begin{array}{c}0.163 \\
(0.155)\end{array}$ & $\begin{array}{c}1.347 * * * \\
(0.267)\end{array}$ \\
\hline Formal protection & $\begin{array}{c}0.159 \\
(0.172)\end{array}$ & $\begin{array}{c}1.207 * * * \\
(0.190)\end{array}$ & $\begin{array}{c}0.121 \\
(0.179)\end{array}$ & $\begin{array}{c}1.260 * * * \\
(0.198)\end{array}$ & $\begin{array}{c}0.982^{* * * *} \\
(0.159)\end{array}$ & $\begin{array}{c}0.413 * * \\
(0.202)\end{array}$ & $\begin{array}{c}1.029 * * * \\
(0.163)\end{array}$ & $\begin{array}{c}0.510^{* *} \\
(0.212)\end{array}$ \\
\hline Competition intensity & $\begin{array}{c}0.412 * * * \\
(0.0996)\end{array}$ & $\begin{array}{c}0.368 * * * \\
(0.134)\end{array}$ & $\begin{array}{c}0.351 * * * \\
(0.102)\end{array}$ & $\begin{array}{l}0.248^{*} \\
(0.138)\end{array}$ & $\begin{array}{c}0.413 * * * \\
(0.0983)\end{array}$ & $\begin{array}{c}0.307 * * \\
(0.140)\end{array}$ & $\begin{array}{c}0.384 * * * \\
(0.0994)\end{array}$ & $\begin{array}{l}0.249 * \\
(0.145)\end{array}$ \\
\hline Size & $\begin{array}{c}0.234 * * * \\
(0.0762)\end{array}$ & $\begin{array}{c}0.609 * * * \\
(0.0941)\end{array}$ & $\begin{array}{c}0.209^{* * *} * \\
(0.0772)\end{array}$ & $\begin{array}{c}0.576 * * * \\
(0.0977)\end{array}$ & $\begin{array}{c}-0.122 \\
(0.0766)\end{array}$ & $\begin{array}{c}0.267 * * * \\
(0.0962)\end{array}$ & $\begin{array}{l}-0.169 * * \\
(0.0791)\end{array}$ & $\begin{array}{c}0.310^{* * *} * \\
(0.0987)\end{array}$ \\
\hline Part of a group & $\begin{array}{l}0.0793 \\
(0.150)\end{array}$ & $\begin{array}{c}0.112 \\
(0.183)\end{array}$ & $\begin{array}{l}-0.100 \\
(0.157)\end{array}$ & $\begin{array}{l}0.0690 \\
(0.191)\end{array}$ & $\begin{array}{c}0.173 \\
(0.152)\end{array}$ & $\begin{array}{l}-0.0867 \\
(0.218)\end{array}$ & $\begin{array}{c}0.198 \\
(0.155)\end{array}$ & $\begin{array}{c}-0.0718 \\
(0.226)\end{array}$ \\
\hline M_Technological opportunity & $\begin{array}{c}0.365 \\
(0.301)\end{array}$ & $\begin{array}{c}1.117 * * * \\
(0.360)\end{array}$ & $\begin{array}{c}0.395 \\
(0.301)\end{array}$ & $\begin{array}{c}0.968 * * * \\
(0.367)\end{array}$ & $\begin{array}{c}0.122 \\
(0.303)\end{array}$ & $\begin{array}{l}0.0308 \\
(0.382)\end{array}$ & $\begin{array}{c}0.125 \\
(0.303)\end{array}$ & $\begin{array}{c}0.217 \\
(0.385)\end{array}$ \\
\hline S_Financial activities & $\begin{array}{c}-1.122 * * * \\
(0.198)\end{array}$ & $\begin{array}{l}-0.328 \\
(0.220)\end{array}$ & $\begin{array}{c}-1.033^{* * *} \\
(0.203)\end{array}$ & $\begin{array}{c}-0.318 \\
(0.228)\end{array}$ & $\begin{array}{l}-0.325^{*} \\
(0.188)\end{array}$ & $\begin{array}{r}-0.0219 \\
(0.219)\end{array}$ & $\begin{array}{l}-0.249 \\
(0.191)\end{array}$ & $\begin{array}{c}0.200 \\
(0.229)\end{array}$ \\
\hline S_Computer activities & $\begin{array}{c}0.371 \\
(0.229)\end{array}$ & $\begin{array}{c}0.859 * * * \\
(0.271)\end{array}$ & $\begin{array}{c}0.129 \\
(0.236)\end{array}$ & $\begin{array}{c}0.587 * * \\
(0.275)\end{array}$ & $\begin{array}{c}1.292^{* * *} * \\
(0.225)\end{array}$ & $\begin{array}{c}1.801 * * * \\
(0.323)\end{array}$ & $\begin{array}{c}1.191 * * * \\
(0.227)\end{array}$ & $\begin{array}{c}2.113 * * * \\
(0.342)\end{array}$ \\
\hline S_R\&D engineering activities & $\begin{array}{c}0.400 \\
(0.249)\end{array}$ & $\begin{array}{l}0.0940 \\
(0.391)\end{array}$ & $\begin{array}{c}0.366 \\
(0.248)\end{array}$ & $\begin{array}{l}0.0861 \\
(0.390)\end{array}$ & $\begin{array}{c}1.448 * * * \\
(0.240)\end{array}$ & $\begin{array}{c}-2.862 * * \\
(1.155)\end{array}$ & $\begin{array}{c}1.425 * * * \\
(0.240)\end{array}$ & $\begin{array}{c}-3.049 * * \\
(1.246)\end{array}$ \\
\hline Constant & $\begin{array}{c}-3.512 * * * \\
(0.452)\end{array}$ & $\begin{array}{c}-6.375^{* * * *} \\
(0.616)\end{array}$ & $\begin{array}{c}-3.213 * * * \\
(0.455)\end{array}$ & $\begin{array}{c}-5.801 * * * \\
(0.624)\end{array}$ & $\begin{array}{c}-3.138 * * * \\
(0.445)\end{array}$ & $\begin{array}{c}-6.199 * * * \\
(0.692)\end{array}$ & $\begin{array}{c}-2.919 * * * \\
(0.447)\end{array}$ & $\begin{array}{c}-6.397 * * * \\
(0.707)\end{array}$ \\
\hline $\begin{array}{l}\text { Observations } \\
\text { Log lik }\end{array}$ & $\begin{array}{c}287 \\
-978.2\end{array}$ & & $\begin{array}{c}287 \\
-946.4\end{array}$ & & $\begin{array}{c}287 \\
-842.3\end{array}$ & & $\begin{array}{c}287 \\
-823.3\end{array}$ & \\
\hline
\end{tabular}

Standard errors in parentheses; $* * * \mathrm{p}<0.01, * * \mathrm{p}<0.05, * \mathrm{p}<0.1$ 
